\title{
TINGKAT KEBUGARAN KARDIORESPIRASI PEMAIN UKM SEPAKBOLA UNIVERSITAS MUHAMM ADIYAH PURWOKERTO TAHUN 2017
}

\author{
Yudha Febrianta dan Sriyanto \\ Universitas Muhammadiyah Purwokerto \\ yudhafebrianta@ump.ac.id
}

\begin{abstract}
ABSTRAK
This study aims to measure the cardiorespiratory fitness of players in the Football Student Activity Association of the Muhammadiyah University of Purwokerto in 2017. This study is a qualitative descriptive method. The population is all players of Football Student Activity Association of the Muhammadiyah University of Purwokerto, with a total of 16 people (respondents). The instrument of the study is the Multi-Stage Test with the reliability of 0.9 and the validity of 0.6. Data analysis techniques used are descriptive with percentages and 6 categories; excellent, very good, good, moderate, lack, and fail. The results show that the level of cardiorespiratory fitness of the football players in the Student Activity Association of the Muhammadiyah University of Purwokerto is in the medium category, no one in the fail and lack category, 8 people (50.00\%) with the moderate category, 4 people $(25.00 \%)$ with the good category, 2 people (12.50\%) with the very good, and 2 people (12.50\%) with the excellent category.
\end{abstract}

Kata Kunci: cardiorespiratory fitness.

\section{PENDAHULUAN}

Kebugaran kardiorespirasi merupakan salah satu komponen terpenting dari kebugaran jasmani. Dengan memiliki kebugaran kardiorespirasi yang baik, pemain dapat melaksanakan aktivitas kesehariannya, tanpa mengalami kelelahan yang berarti, di samping itu jantung dan paru dapat berfungsi secara optimal, sehingga penyakit jantung dapat dihindari (Wahjoedi, 2000: 54).

Klub UKM Sepakbola Universitas Muhammadiyah Purwokerto dipilih o leh peneliti sebagai objek Penelitian karena klub UKM Sepakbola UMP ini paling menonjol diantara klub-klub yang ada di Banyumas karena tahun 2016 dikirim mewakili Rayo n III mengikut i ajang POMRAYON di Magelang. Prestasi yang sudah diraih antara lain juara I pada RAYON III 2013, juara I pada Piala Rektor UMP 2014. Namun dalam hal kebugaran kardiorespirasi klub ini 
pada saat pertandingan baik kompet isi/turnamen maupun uji coba, pemain UKM Sepakbola UMP terlihat kelelahan pada saat bertanding.

Kurangnya akt ivitas yang dilakukan o leh pemain dan belum adanya latihan kebugaran, dapat diduga pemain UKM Sepakbola UMP memiliki kebugaran kardiorespirasi yang kurang baik. Namun, hal ini barulah dugaan awal dan perlu dicari kebenaranya melalui Penelitian. Untuk mencapai prestasi yang maksimal, diperlukan kebugaran jasmani yang baik dari seorang at let. Dan untuk mendapatkan kebugaran jasmani yang baik, diperlukan kekuatan jantung dan paru yang baik, latihan yang teratur, terencana, dan terprogram. Seorang atlet, apabila mempunyai kebugaran kardiorespirasi yang baik tentunya akan mampu melakukan segala sesuatu yang berkaitan dengan aktivitas yang dilakukan sesuai dengan spesifikasi bidang olahraga yang dimiliki. Atlet dengan $\mathrm{t}$ ingkat kebugaran kardiorespirasi atau daya tahan jantung dan paru yang baik, prestasinya pasti akan lebih optimal dibanding dengan at let yang mempunyai tingkat kebugaran yang lebih rendah. Untuk itu, diperlukan upaya untuk dapat meningkatkan kebugaran kardiorespirasi oleh seorang atlet sehingga akan mendaptkan prestasi yang lebih optimal.

Kebugaran jasmani memegang peranan pent ing dalam pencapaian prestasi. Menurut Iskandar Z. Adisapoetro (1999: 64), kebugaran jasmani yang baik akan berdampak posit if terhadap: (1) peningkatan kemampuan sirkulasi darah dan kerja jantung; (2) peningkatan kekuatan, kelentukan, daya tahan, koordinasi, keseimbangan, kecepatan, dan kelincahan; (3) peningkatan kemampuan gerak secara efisien; (4) peningkatan kemampuan pemulihan organ tubuh setelah latihan; dan (5) peningkatan kemampuan merespon dengan cepat.

Peningkatan daya tahan jantung dan paru pada seseorang tersebut bukan tanpa proses, tetapi melalui lat ihan yang terprogram, yang dapat dipantau melalui pelaksanaan tes kebugaran yang dilakukan secara berkala. Hasil tes kebugaran kardiorespirasi dapat digunakan oleh seorang pelatih untuk mengukur, mengarahkan, dan memberikan informasi kepada at letnya mengenai t ingkat kebugaran jasmaninya. Hasil tes kebugaran kardiorespirasi tersebut 
merupakan modal untuk para pelat ih, agar dapat meningkatkan prestasi atletatletnya.

\section{Pembahasan}

\section{A. Kebugaran Kardiorepirasi}

Menurut Rush Lutan (2001:46), secara teknis pengertian cardio (jantung), vaskuler (pembuluh darah), respirasi (paru-paru dan ventilasi), aerobic (bekerja dengan oksigen). Istilah ini berkaitan satu sama lain.

Cardiorespiratory system is composed cardiovascular and respiratory system (Clark, 2001: 41). Kardiorespirasi merupakan sistem kerja fungsi faal tubuh manusia yang meliputi sistem kardiovaskuler dan respirasi.

1) Sistem Kardiovaskuler

Jantung merupakan organ berongga, berotot dan berbentuk kerucut yang terletak diantara paru-paru kiri dan kanan, di daerah yang disebut mediastinum, di belakang badan sternum, dan dua pertiganya terletak di sebelah kiri (Waston, 2002: 245). Adapun fungsi jantung menurut

Sherwood (2001: 257) adalah sebagai po mpa yang melakukan tekanan terhadap darah untuk menimbulkan gradient tekanan yang diperlukan agar darah dapat mengalir ke jaringan. Oleh karena itu, dapat dikatakan bahwa jantung adalah organ dalam tubuh manusia yang berongga, berotot, dan berbentuk kerucut dengan ukuran kira-kira satu kepalan tangan yang berfungsi untuk memo mpa darah dengan kandungan oksigen $t$ inggi ke seluruh jaringan tubuh melalui pembuluh darah sebagai energi dalam beraktivitas. Dengan kata lain sistem kardiovaskuler dapat membantu menyatukan tubuh sebagai suatu kesatuan dan sebagai alur nutrusi Berta oksigen yang berlangsung secara terus-menerus melalui darah, sehingga energi yang diperlukan oleh tubuh dalam periode tertentu dapat dipertahankan.

Jantung merupakan organ berotot yang terbentuk dari otot-otot bergaris seperti otot rangka, otot ini Bering dinamakan otot jantung. Otot jantung ini meskipun menyerupai otot rangka, akan tetapi memiliki sistem kerja yang berbeda. Otot rangka bekerja dipengaruhi oleh kehendak, sedangkan otot jantung $t$ idak dipengaruhi oleh kehendak. Menurut Junusul (1989: 146), 
jaringan otot jantung memiliki sifat authorhytmicity yang artinya jantung berkontraksi $t$ idak memerlukan adanya impuls dari syaraf, kontraksi otot jantung disebabkan oleh gelo mbang depolarisasi yang berasal dari bagian kecil pada jaringan khusus di atrium yang dinamakan Sino Atrial (S- A) node atau pacemaker.

Jantung berkontraksi sekitar 70-80 kali permenit sepanjang hidup, akan tetapi frekuensinya berbeda-beda tergantung usia, emosi, lat ihan fisik, dan lain-lain. Dari proses berkontraksinya otot ini dapat diketahui dari luar yaitu melalui perhitungan denyut nadi. Tempat terbaik untuk menghitung denyut nadi adalah pada pergelangan tangan, sisi kiri dada, di daerah terletaknya jantung dan di samping tenggorokan (Janssen, 1993:27). Frekuensi denyut nadi ini dapat digunakan sebagai indikasi kemampuan jantung dalam memo mpa darah ke seluruh jaringan tubuh, sehingga dapat dikatakan pula bahwa dengan melihat frekuensi denyut jantung dapat digunakan untuk mengetahui kebugaran jantung. Hal ini dapat disimpulkan bahwa semakin sedikit frekuensi denyut jantung ist irahat per menit, maka semakin bugar jantungnya. Demikian pula sebaliknya semakin banyak frekuensi denyut jantung ist irahat per menit menunjukkan bahwa kebugaran jantungnya mengalami penurunan.

Menurut Waston (2002: 257), ada beberapa faktor yang mempengaruhi frekuensi denyut jantung yaitu: (1) istirahat dapat menurunkan frekuensi denyut jantung, sedangkan lat ihan fisik dapat meningkatkan frekuensi denyut jantung; (2) peningkatan usia dapat menurunkan frekuensi denyut jantung, seperti pada bayi frekuensi denyut jantung antara 120-140 per menit saat lahir dan frekuensi ini akan menurun seiring peningkatan usia; (3) seorang wanita memiliki frekuensi denyut jantung sedikit lebih cepat dibanding pria; (4) emo si dan eksitasi akan mempercepat frekuensi denyut jantung. Jadi dapat disimpulkan bahwa pada saat ist irahat denyut jantung akan mengalami penurunan, sedangkan pada saat lat ihan akan mengalami peningkatan yang dapat melath daya tahan jantung dalam berdenyut. Apabila seseorang sering melakukan latihan fisik denyut jantung istirahat juga mengalami penurunan. 


\section{2). Sistem Respirasi}

Respirasi atau pernapasan adalah pertukaran gas yang terjadi antara organisms tubuh dengan lingkungan sekitarnya (Junusul, 1989:118). Respirasi ini melibatkan seluruh proses yang menyebabkan pergerakan secara pasif oksigen $\left(\mathrm{O}_{2}\right.$ ) dari lingkungan sekitarnya (udara) ke paru-paru, dan dilanjutkan ke seluruh jaringan tubuh guna menunjang proses metabo lisme, serta pergerakan secara pasif karbon dioksida $\left(\mathrm{CO}_{2}\right)$ yang merupakan sisa metabolisme dari jaringan kemudian keluar ke udara. Jadi dapat disimpulkan bahwa fungsi utama dari respirasi adalah untuk mendapatkan $\left(\mathrm{O}_{2}\right)$ dari udara yang dialirkan ke seluruh jaringan tubuh, agar dapat membantu dalam proses metabolisme energi dan membawa keluar $\mathrm{CO}_{2}$ yang dihasilkan oleh sel. Menurut Waston (2002: 296), organ-organ sistem pernafasan terdir i dari: hidung, faring, laring, trakea, bronkus, bronkiolus, alvio li dan duktus alvio laris. Dari fungsi organ-organ pernapasan tersebut menghasilkan mekanisme pernapasan yaitu inspirasi dan ekspirasi. Inspirasi adalah proses masuknya udara dari luar yang kaya oksigen ke dalam paru. Sedangkan ekspirasi merupakan proses keluarnya karbon dioksida dari paru-paru.

Secara umum proses respirasi dapat dibagi menjadi tiga bagian, yaitu pernapasan luar (external respiration), pernapasan dalam (internal respiration), dan pernapasan seluler (cellular respiration). Pernapasan luar adalah proses pengambilan oksigen dari udara masuk ke dalam alvio li paru dan selanjutnya masuk ke dalam darah. Pernapasan dalam yaitu proses berjalannya oksigen ke seluruh jaringan tubuh yang dibawa oleh darah, sedangkan pernapasan selular merupakan proses penggunaan oksigen oleh sel-sel tubuh yang dapat menghasilkan energi, air, dan karbondioksida.

Cardiorespiratory fitness means that one is able to run, swim, cycle, play vigours sports, or engage in heavy occupational labour for prolonged periods of time because the heart and lung systems are able to transport oxygen to the working muscles, allowing body fuel stores to be burned for energy (Nieman, 1993: 47). Dari uraian di atas dapat disimpulkan bahwa kemampuan kardiorespirasi merupakan kema mpuan paru dan jantung untuk mensuplai oksigen ke seluruh jaringan sel tubuh sebagai energi untuk dapat 
melakukan akt ivitas fisik seperti lari, berenang, bersepeda, olahraga permainan, dan lain-lain.

Adapun cara yang harus dilakukan untuk dapat mengetahui kemampuan kardiorespirasi seseorang maka harus dapat diketahui konsumsi oksigen mansimal atau kapasitas $\mathrm{VO}_{2}$ max. Konsumsi oksigen maksimal atau kapasitas VO2 max adalah ambilan oksigen selama eksersi maksimum (Janssen, 1993: 26). Menurut (Junusul, 1989:186), perbedaan yang terbesar antara oksigen yang dihisap masuk ke dalam paru dan oksigen yang dihembuskan ke luar paru VO2 max dinyatakan dala $\mathrm{m}$ liter/menit. Kinerja pada tingkat $\mathrm{VO}_{2}$ max hanya dapat dipertahankan untuk jangka waktu yang sangat pendek dan paling lama beberapa menit (Janssen, 1993: 26).

Menurut Santosa (2007:393), ambilan oksigen maksimal adalah ukuran mengenai kemampuan gabungan dari otot-otot yang berkontraksi untuk mengkonsumsi oksigen bagi keperluan mengo lah sumber energi dengan kemampuan kemo-hidro-limfatik, sistem respirasi dan sistem kardiovaskuler. Maximal aerobik power sering kali disebut penggunaan oksigen maksimal, adalah tempo tercepat dimana seseorang dapat menggunakan oksigen selama olahraga. VO2 max mengacu pada kecepatan pemakaian oksigen, bukan sekedar banyaknya oksigen yang dipakai. Sebagai contoh, sesungguhnya set lap orang sanggup untuk memakai 5 liter oksigen bila diberi waktu yang cukup panjang untuk itu. Jadi dapat dikatakan bahwa ambilan oksigen maksimal (VO2 max) ukuran kemampuan otot yang berkontraksi untuk mengkonsumsi oksigen yang dipero leh dari sistem respirasi dan kardiovasculer (kardiorespirasi).

Menurut Junusul (1989: 188) menyatakan bahwa fungsi fisiologis yang terlibat di dalam kapasitas konsumsi oksigen maksimal ( $\mathrm{VO}_{2}$ max) adalah: (1) jantung, paru, dan pembuluh darah harus berfungsi dengan baik, sehingga oksigen yang dihisap masuk ke paru dan selanjutnya sampai ke darah; (2) proses penyampaian oksigen ke jaringan-jaringan oleh sel-sel darah merah harus normal yakni fungsi jantung, volume darah, sel-sel darah merah, dan konsentrasi hemoglobin serta pembuluh darah harus mampu mengalihkan darah 
dari jaringan-jaringan yang tidak aktif ke otot yang sedang aktif yang membutuhkan oksigen lebih besar; (3) jaringan-jaringan terutama otot, harus mempunyai kapasitas yang normal untuk mempergunakan oksigen yang disampaikan kepadanya. metabolisme dan fungsi mitokondria harus normal.

Pada saat bermain sepakbola sangat diperlukan energi secaraaerobik yang diperoleh dari suplai oksigen keseluruhan tubuh sebagai energi. Oleh sebab itu, setiap pemain sepakbola harus memiliki kemampuan kardiorespirasi agar pemenuhan oksigen dapat berjalan dengan lancar. Apabila seseorang at let mempunyai daya tahan kardiorespirasi yang baik maka pada saat bermain sepakbola $t$ idak akan merasakan kelelahan yang berarti, sehingga penampilan dalam bermain sepakbola akan optimal. Dalam proses menentukan besarnya kemampuan kardiorespirasi maka diperlukan pengukuran oksigen yang digunakan maksimal (ambilan oksigen maksimal) atau $\mathrm{VO}_{2}$ max secara langsung untuk beraktivitas. Salah satu bentuk tes lapangan yang digunakan untuk mengetahui VO2 max adalah multi stage fitness test. Bentuk tes multi stage ini mempunyai beberapa kelebihan, diantaranya data VO2 max lebih akurat apabila dibandingkan dengan tes lapangan lainnya dan dapat dilaksanakan secara massal. Pelaksanaan tes ini relat if lebih mudah dan menggunakan area atau daerah yang tidak luas.

Menurut Wahjoedi (2006:61) diantara keempat komponen kebugaran jasmani (daya tahan kardiorespirasi, daya tahan otot, kekuatan otot, dan fleksibilitas), daya tahan kardiorespirasi dianggap ko mponen paling pokok dalam kebugaran jasmani. Daya tahan kardiorespirasi sangat pent ing untuk menunjang kerja otot dengan pengambilan oksigen dan menyalurkan keseluruh jaringan otot yang sedang aktif sehingga dapat digunakan untuk metabo lisme. Berdasarkan penelitian yang dikemukakan Rush Lutan, dkk (2001:46), manfaat pembinaan daya tahan kardiorespirasi dapat mengurangi resiko tekanan darah tinggi, penyakit jantung koroner, kegemukan, diabetes, kanker, masalah kesehatan orang dewasa.

Daya tahan kardiorespirasi adalah kesanggupan sistem jantung, paru dan pembuluh darah untuk berfungsi secara optimal pada keadaan ist irahat 
dan kerja dalam mengambil oksigen dan menyalurkan ke jaringan yang aktif sehingga dapat dipergunakan pada proses metabo lisme tubuh (Soedijarto, 1997:5). Menurut Fox, dkk (1987:8), daya tahan kardiorespirasi atau kebugaran kardiovaskuler mengacu pada kemampuan sistem jantung, dan paru untuk mengirimkan karbondioksida dari otot- otot kerja selama aktivitas lat ihan yang lama. Kardiorespirasi adalah kemampuan dari jantung, paru, pembuluh darah, dan kelo mpok otot yang besar untuk melakukan lat ihan-lat inan yang keras dalam waktu yang lama, seperti jogging, berenang, senam aerobik, bersepeda, mendayung, dan lain sebagainya (Len Kravitz, 2001:5).

Dari beberapa pendapat diatas dapat disimpulkan bahwa kebugaran kardiorespirasi adalah ukuran kemampuan paru-paru jantung dalam mensuplai oksigen dalam darah ke seluruh tubuh pada saat melakukan aktivitas fisik yang dilakukan secara terus menerus. Kebugaran kardiorespirasi dapat diukur dengan memantau penyerapan oksigen maksimum yang yan dikenal dengan ist ilah VO2 Maks.

\section{B. Manfaat Kebugaran Kardiorespirasi}

Sadoso Sumosardjuno (1996:9) menyatakan bahwa bagi mereka yang berlat in olahraga aerobik secara teratur akan mendapat beberapa keuntungan, antara lain:

1) berkurangnya resiko gangguan pada jantung dan peredaran darah;

2) tekanan darahnya yang sebelumnya tinggi akan menurun secara teratur;

3) menurunnya kadar lemak yang membahayakan didalam darah dan terjadi kenaikan kadar lemak yang baik yang bermaanfaat bagi tubuh;

4) tulang-tulang, persendian, dan otot-otot menjadi lebih kuat (tergantung jenis latihannya).

Kebugaran kardiorespirasi dapat diukur dengan menggunakan tes lapangan yang tujuannya untuk mengetahui seberapa besar tingkat VO2 Maks dengan menggunakan lari multi tahap (multy stage).

\section{Hakikat Sepakbola}

Yudha Febrianta, Tingkat Kebugaran Kardiorespirasi Pemain UKM Sepakbola Universitas Muhammadiyah Purwokerto Tahun 2017 
Sepakbola adalah suatu permainan yang sangat populer di dunia. Jika dibandingkan dengan cabang permainan olahraga yang lain, permainan sepakbola mempunyai daya tarik tersendiri. Menurut Tarigan (2001: 2), daya tarik tersebut diantaranya memperagakan kemampuan dalam mengolah bola, penampilan yang sungguh-sungguh dan penuh perjuangan dalam bermain, gerakan yang dinamis disertai dengan kejutan-kejutan taktik yang membuat penonton kagum melihatnya.

Permainan sepakbola merupakan cabang olahraga yang cukup kompleks dalam pelaksanaan permainannya, sehingga harus menuntut para pemainnya mampu memecahkan masalah yang terjadi di dalam permainan. Seperti, bagaimana seorang pemain menjaga dan mengatur kebugaranya agar tenaga yang dikeluarkan saat bermain bisa efektif dan efisien sehingga tidak mudah lelah serta mampu melakukan teknik gerakan dengan tepat. Selain itu, penguasaan teknik, taktik dan strategi, serta mental yang bagus tidak kalah pent ingnya dalam permainan sepakbola untuk memperoleh hasil yang diharapkan, yaitu kemenangan.

Dalam sepakbola terdapat beberapa teknik dasar diantaranya: passing, controlling, dribbling, shooting, heading. Jika teknik dasar di atas sudah dikuasai dengan baik oleh seorang pemain sepakbola, maka dia bisa bermain sepakbola dengan baik. Jika pemain tersebut ingin meningkatkan kemampuan bermain sepakbolanya maka pemain tersebut harus latihan dengan rajin dan serius dalam latihan sehingga pemain tersebut bisa berprestasi. Selain memilik $i$ teknik dasar di atas para pemain sepakbola harus memiliki mental yang baik, baik di dalam maupun luar lapangan.

Prinsip dalam permainan sepakbola cukup sederhana, yaitu berusaha memasukkan bola ke gawang lawan sebanyak mungkin dan berusaha menggagalkan serangan lawan untuk melindungi atau menjaga agar gawangnya tidak kemasukan bola. Menurut Sneyers (1988: 3), prinsip dalam sepakbola sederhana sekali yaitu membuat gol dan mencegah agar jangan sampai lawan berbuat hat yang sama terhadap gawang sendiri. Menurut Soekatamsi (1995: 11), tujuan dari masing-masing regu atau kesebelasan adalah berusaha memasukkan bola ke dalam gawang lawan sebanyak mungkin 
dan berusaha menggagalkan serangan lawan untuk melindungi gawangnya agar tidak kemasukan.

Berdasarkan prinsip tersebut dapat diketahui bahwa tujuan utama permainan sepakbola adalah mencetak gol ke gawang lawan sebanyakbanyaknya dan berusaha menggagalkan setiap serangan dari lawan yang ingin memasukkan bola ke gawangnya dengan sportif, tidak bertentangan dengan peraturan yang berlaku.

\section{Profil Tim Sepakbola Universitas Muhammadiyah Purwokerto}

Tim UKM Sepakbola Universitas Muhammadiyah Purwokerto merupakan salah satu tim Universitas yang ada di Kabupaten Banyumas. Tujuan didirikannya tim UKM Sepakbola Universitas Muhammadiyah Purwokerto adalah untuk mewadah kegiatan mahasiswa dan memajukan olahraga sepakbola yang berada di wilayah kabupaten Banyumas, serta mewujudkan tim kesebelasan yang memiliki prestasi yang dapat dibanggakan baik di tingkat regional maupun di tingkat nasio nal. Jenis kegiatan yang ada, hampir sama dengan tim-tim sepakbola pada umumnya. Disini, terjadi proses berlat ih, untuk melat ih keterampilan bermain sepakbo la. Materi yang diajarkan tidak hanya terbatas pada keterampilan bermain sepak bola saja, tetapi juga sampai pada pengembangan kemampuan fisik, taktik dan mental bertanding.

Proses latihan, berlangsung selama 3 kali dalam satu minggu. Set iap hari Senin, Selasa dan Kamis sore jam 16.00 wib di lapangan Universitas Muhammadiyah Purwokerto. Tujuan didirikannya tim UKM Sepakbola Universitas Muhammadiyah Purwokerto ini adalah untuk wadah kegiatan mahasiswa yang lebih bermanfaat dan mengembangkan minat serta bakat yang dimiliki mahasiswa.

Untuk memajukan olahraga sepakbo la Tim UKM Sepakbo la Universias Muhammadiyah Purwokerto di Banyumas, Tim sering mengadakan lat ihan uji coba, baik di dalam wilayah kabupaten Banyumas maupun di luar kabupaten Banyumas. Latihan uji coba ini dilakukan tidak hanya dengan sesama klub sepakbola wanita, tetapi juga dengan klub sepakbola disekitar Banyumas. Lat ihan uji coba ini dimaksudkan agar para pemain yang rata-rata masih muda 
karena mahasiswa tidak mengalami kejenuhan saat berlatih. Selain itu, hal in juga dilakukan sebagai persiapan untuk mewakili Universitas Muhammadiyah.

\section{E. Metodologi Penelitian}

Penelitian ini adalah Penelitian deskript if. Penelitian ini hanya ingin menggabarkan situasi yang saat ini sedang berlangsung tanpa adanya pengujian hipotesis. Penelitian deskriptif adalah Penelitian yang dilakukan terhadap variabel tunggal yang $t$ idak membuat perbandingan atau menghubungkan dengan variabe I lain (Sugiyo no, 2006: 21). Metode yang digunakan dalam Penelitian ini adalah metode survei dengan teknik tes dan pengukuran. Penelitian ini dilakukan di lapangan sepakbola Universitas Muhammadiyah Purwokerto, Banyumas dengan memberikan tes pada responden untuk mendapatkan data yang diperlukan.

\section{F. Teknik Analisis Data}

Data yang terkumpul dalam satuan waktu kemudian dikonversikan ke dalam tabel norma penilaian $\mathrm{VO}_{2} \max$ (multi leverl). Setelah seluruh data dikonversikan ke dalam tabel, kemudian data dianalisis dengan cara deskript if presentase untuk mengetahui kebugaran jasmani pemain sepakbo la UKM Sepakbo la Universitas Muhammadiyah Purwokerto, Banyumas.

Tabel norma kebugaran untuk tes multi stage yang digunakan adalah untuk usia 20-29 tahun dengan pembagian katagori adalah sebagai berikut:

Tabel 2.

Norma Kebugaran untuk Tes Multi Stage untuk Usia 20-29 Tahun

\begin{tabular}{|l|l|}
\hline \multicolumn{1}{|c|}{ Skor } & \multicolumn{1}{c|}{ Kategori } \\
\hline$<38$ & Kurang Sekali \\
\hline $39-43$ & Kurang \\
\hline $44-51$ & Cukup \\
\hline $52-56$ & Baik \\
\hline $57-62$ & Baik Sekali \\
\hline
\end{tabular}




\section{G. Hasil Penelitian}

Analisis terhadap hasil tes multistage yang mencerminkan tingkat kebugaran kardiorespirasi pemain sepakbola UKM Sepakbola Universitas Muhammadiyah Purwokerto menghasilkan rerata sebesar 33,37 median 30,52 modus 30,18 dan SD sebesar 4,6. Distribusi frekuensi tingkat kebugaran kardiorespirasi pemain sepakbola UKM Sepakbola Universitas Muhammadiyah Purwokerto adalah dalam tabel sebagai berikut:

Tabel 4.

Distribusi Frekuensi Tingkat Kebugaran Kardiorespirasi Pemain Sepakbola UKM Sepakbola Universitas Muhammadiyah Purwokerto

\begin{tabular}{|c|c|c|c|}
\hline Interval & Kategori & $\mathbf{F}$ & $\%$ \\
\hline$<23,6$ & $\begin{array}{l}\text { Sangat } \\
\text { Kurang }\end{array}$ & 0 & $0,00 \%$ \\
\hline $23,6-28,9$ & Kurang & 0 & $0,00 \%$ \\
\hline $29,0-32,9$ & Sedang & 8 & $50,00 \%$ \\
\hline $33,0-36,9$ & Baik & 4 & $25,00 \%$ \\
\hline $37,0-41,0$ & Sangat Baik & 2 & $12,50 \%$ \\
\hline $41,0<$ & Istimewa & 2 & $12,50 \%$ \\
\hline \multicolumn{2}{|c|}{ Jumlah } & 16 & $100.00 \%$ \\
\hline
\end{tabular}

Berdasarkan tabel di atas tampak tingkat kebugaran kardiorespirasi pemain sepakbola UKM Sepakbola Universitas Muhammadiyah Purwokerto yang berada pada katagori istimewa sebanyak 0 orang $(00,00 \%)$, kurang sebanyak 0 orang $(00,00 \%)$, sedang sebanyak 8 orang $(50,00 \%)$. Baik sebanyak 4 orang $(25,00)$, sangat baik sebanyak 2 orang atau (12,50\%), dan istimewa sebanyak 2 orang atau $(12,50 \%)$.

Di bawah ini akan digambarkan diagram hasil tingkat kebugaran kardiorespirasi pemain sepakbola UKM Sepakbola Universitas Muhammadiyah Purwokerto sebagi berikut. 


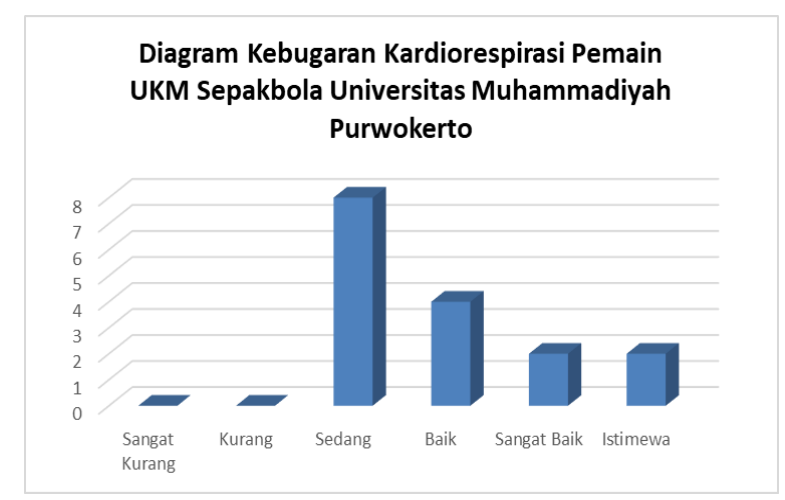

Gambar 1. Diagram Kebugaran Kardiorespirasi Pemain UKM Sepakbola Universitas Muhammadiyah Purwokerto

Dari perhitungan diatas maka status tingkat kebugaran kardiorespirasi pemain sepakbola UKM Sepakbola Universitas Muhammadiyah Purwokerto yang berada pada katagori istimewa sebanyak 0 orang $(00,00 \%)$, kurang sebanyak 0 orang $(00,00 \%)$, sedang sebanyak 8 orang $(50,00 \%)$. Baik sebanyak 4 orang $(25,00)$, sangat baik sebanyak 2 orang atau $(12,50 \%)$, dan istimewa sebanyak 2 orang atau (12,50\%).

Kebugaran kardioerspirasi adalah komponen paling penting dalam kebugaran jasmani seseorang. Kebugaran kardiorespirasi atau daya tahan jantung, paru adalah kemampuan jantung paru dalam menyerap dan mendistribusikan oksigen ke otot-otot yang bekerja sesuai dengan kebutuhan. Seseorang yang mempunyai tingkat kebugaran kardioerpirasi yang baik akan lebih efisien dalam penggunaan oksigen sehingga dapat melakukan aktivitas sehari-hari tanpa mengalami kelelahan.

Pemain UKM Sepakbola Universitas Muhammadiyah Purwokerto yang memiliki kebugaran kardiorespirasi dengan katagori sedang dikarenakan aktivitas fisik sendiri akan mempengaruhi semua komponen kebugaran, sehingga salah satu bentuk aktivitas fisik yang rutin dilakukan oleh pemain UKM Sepakbola adalah latihan yang bersifat aerobik. Latihan yang bersifat aerobik dapat meningkatkan daya tahan kardiorespirasi dan dapat mengurangi lemak tubuh.

Kebugaran kardiorespirasi dipengaruhi oleh kabiasaan latihan, kebiasaan latihan yang dilakukan oleh putri bantul akan membentuk kardio respirasi yang sangat bagus. Pemain UKM Sepakbola UMP berasal dari berbagai kalangan di 
wilayah provinsi Jawa Tengah, serta dari berbagai tingkat pendidikan dalam masyarakat. Usia juga mempengaruhi kebugaran kardiorespirasi, usia menentukan kekuatan serta daya tahan jantung paru. Para pemain UKM Sepkboa mempunyai variasi usia yang berbeda-beda yaitu antara 20-29 tahun. Tentu saja hal ini mempengaruhi hasil tes kebugaran kardiorespirasi. Usia akan membentuk struktuur tubuh serta pembentukan otot-otot ditubuh para pemain sepakbola, sehingga untuk melakukan tes kebugaran bisa dilakukan karena tubuh sudah mendukung sehingga bisa melakukan secara maksimal.

Motivasi dari pemain UKM sepakbola UMP juga mempengaruhi tingkat kebugaraan kardiorespirasi pemain. Pemain yang memahami prospek dari segi prestasi dari cabang olahraga sepakbola yang cukup prospektif membuat pemain sepakbola termotivasi untuk meningkatkan kemampuan pemain sendiri, termasuk kebugaraan kardiorespirasi pemain. Kebugaran kardioerspirasi akan menunjang prestasi pemain, apalagi faktor ini berhubungan erat dengan kemampuan tubuh untuk melakukan latihan tanpa kelelahan yang berarti.

Kesibukan di luar lapangan para pemain juga berpengaruh terhadap kebugaraan kardiorespirasi pemain. Artinya kesibukan di luar latihan akan mempengaruhi aktivitas latihan, terutama dari segi fisik. Salah satu contoh adalah aktivitas kuliah dan kegiatan belajar di Kampus. Aktivitas kuliah merupakan aktivitas rutin yang dilakukan oleh semua pemain UKM Sepakbola UMP. Aktivitas ini akan mempengaruhi dari segi waktu, apalagi saat tugas dan kesibukan belajar yang padat. Akan tetapi para pemain dapat membagi waktu antara latihan fisik dengan kegiatan belajarnya di kampus.

\section{DAFTAR PUSTAKA}

Arma Abdoelah. (1981). Olahraga untuk Perguruan Tinggi. Yogyakarta: Sastra Hudaya.

Brian J. Sharkey. (2003). Kebugaran dan Kesehatan. Jakarta : PT. Raja Grafindo Persada.

Depdiknas. (2000). Pedoman Modul Pelatihan Kesehatan Olahraga bagi Pelatihan Olahragawan Pelajar. Jakarta: Depdinas.

Djoko Pekik I. (2004). Panduan Latihan Kebugaran. Yogyakarta: Lukman Offset.

Fox E. L. (1984). Sport physiology, second edit ion. Ohio State University: CBS College Publinshing. 
Janseen, P. G. J. M. (1993). Training-Lactate-Pulse Rate. (M.M. Pronggotmodjo. Terjemahan). Jakarta: PT Tempirint. Buku asli diterbitkan tahun 1989. Junusul Hairy. (1989). Fisiologi Olahraga. Jakarta: Depdikbud.

Len Krevitz. (2001). Panduan Lengkap Bugar Total. Jakarta : PT. Raja Grafindo Persada.

Muchamad Sajoto. (1988). Pembinaan Kondisi Fisik dalam Olahraga. Jakarta: Dirjen Dikti P2LPTK Depdikbud.

Nieman, D. C. (1993). Fitness \& your health. Palo Alto, California: Bull Publihsing Company.

Nurhasan. (2005). Aktifitas Kebugaran . Jakarta : Depdiknas

Rusli Lutan, dkk. (2000). Dasar-dasar Kepelatihan. Jakarta: Dirjen Pendidikan Dasar dan Menegah.

Rusli Lutan, dkk. (2001). Asas-asas Pendidikan Jasmani. Jakarta : Dirjen Olahraga Depdiknas.

Rusli Lutan, dkk. (2002). Menuju Sehat Bugar. Jakarta: Debdikbud.

Sadoso S. (1992). Pengetahuan Praktis Kesehatan Olahraga. Jakarta: Pustaka

Kartini. Suharsimi Ar ikunto. (2002). Prosedur Penelitian Suatu Pendekatan Praktek. Jakarta: Rineka Cipta.

Sherwood Lauralee. (2001). Human Physiology: From Cells to System. (Brahm U. Pendit. Terjemahan). Jakarta: Penerbit Buku kedokteran EGC. Buku asli diterbitkan tahun 1996.

Wahjoedi (2000). Landasan Evaluasi Pendidikan Jasmani. Jakarta: PT. Raja Grafindo Perkasa.

Waston, Roger. (2002). Anatomy and Physiology for Nurses. (Sitti Syabariah. Terjemahan). Jakarta: Penerbit Buku Kedokteran EGC. Buku asli diterbitkan tahun 1995. 